\title{
Impact of KSAMBS' free SMS to farmers on agricultural marketing prices- a case study in Karnataka (India)
}

\author{
Ganeshagouda I. Patil ${ }^{1}$, Parmod Kumar², Manjunatha A. V. ${ }^{2}$, Somanagouda I. Patil ${ }^{3}$, \\ Vijayachandra Reddy S. ${ }^{4}$, Ramasundaram P. ${ }^{1}$ \\ ${ }^{1}$ National Centre for Agricultural Economics and Policy Research, New Delhi -12, India \\ ${ }^{2}$ Agricultural Development and Rural Transformation Centre, Institute for Social and Economic Change, Bangalore -72, India \\ ${ }^{3}$ Department of Agricultural Economics, University of Agricultural sciences, Dharwad-05, India \\ ${ }^{4}$ Department of Agri-Business Management, University of Agricultural sciences, Dharwad-05, India
}

Email address:

ganeshncap@gmail.com(G. I. Patil)

\section{To cite this article:}

Ganeshagouda I. Patil, Parmod Kumar, Manjunatha A. V. , Somanagouda I. Patil, Vijayachandra Reddy S., Ramasundaram P. Impact of KSAMBS' Free SMS to Farmers on Agricultural Marketing Prices- A Case Study in Karnataka (India). Science Discovery. Vol. 1, No. 3, 2013, pp. 28-34. doi: 10.11648/j.sd.20130103.12

\begin{abstract}
This paper analyzes the impact of Karnataka State Agricultural Marketing Board (KSAMBs') free SMS (Short Message Service) to farmers on agricultural marketing prices using primary (from 110 farmers) and secondary information (from KSAMB and NIC). From the secondary data, it was found that about 89.26 percent of the registered users (120071 numbers) were farmers. Results from the primary data showed higher share of SMS beneficiaries in the age group of 25 to 40 years $(46.36 \%)$. Further around 95.5 percent of the farmers were educated, who had expressed satisfaction about the SMS information received in local and English languages. Most of the medium and large farmers (52\%) had benefited from selling their produce based on the free SMS on price information. It is interesting to note that about 88.18 percent of the beneficiary farmers had shared the price information to other farmers. A majority of the farmers $(80 \%)$ opined that disseminated information was simple, timely, understandable and accurate, which helped them in fetching better price. Results of study provide useful insights to the policy makers for enhancing the benefits as well as further improvement of the service delivery.
\end{abstract}

Keywords: SMS, Agricultural Marketing, Dissemination, Information, Karnataka

\section{Introduction}

The agricultural sector plays an important role in the Indian economy, contributing 52 per cent to the employment and 15 per cent to the gross domestic product (Civil services chronicle April, 2012). The country is characterized by great diversity in climatic conditions, soil conditions, temperature, rainfall variation, farm size, level of technology adoption, etc. This has imposed great challenges to the policy makers to frame policies of agricultural development. Thus the Union and State governments, research institutions and agricultural universities have been increasingly putting efforts in improving productivity and farm profitability. The bane of Indian agriculture is not lack of technologies and $R \& D$ efforts but inadequate and inefficient dissemination of relevant information to the farmers (Bahl, 2008). In most of the developing countries, much of the agricultural information is traditional and some times outdated and not applicable to small farmers' needs, leaving such a farmers with little information or resources to improve their productivity (Meera et al., 2004). The timely availability of right information for its right purpose in its proper utilization of major inputs required for farming. Information and Communication Technology (ICT) can act as a driving force in the agricultural development process (Chahal et al 2012). The information facilitates the farmers to decide what and when to plan, how to cultivate, when and how to harvest, what post-harvest management practices to fallow, when and where to market the produce, etc. (USAID, 2010). By understanding the importance of the information in agriculture development and agribusiness, various players have been entered in to market information dissemination using ICT, of them are IFFCO (Indian Farmers Fertilizers Co-operative Ltd.), Kisan Sanchar Limited, Reuters Market Light (RML), and Nokia 
Life Tool (NLT) etc., have charging some nominal or minimal prices for availing the information. In a similar fashion, the Karnataka State Agricultural Marketing Board (KSAMB) has also initiated dissemination of market prices at free of cost through mobile SMS alerts to the farming community. Apart from these, it is also disseminating same market information using other means like daily local news paper, televisions, www. krishimaratavahini.nic.in, www. Agmarknet.nic.in and Kisan Call Centres.

\section{Importance of KSAMB in Dissemination of Market Information}

The 'Krishimaratavahini' website provides information to the market stakeholders about minimum, maximum and modal prices and arrivals of all the notified commodities for all the regulated markets in the state. Due to its attractive services, user-friendly design of website and its usefulness to the farming community, the Ministry of communication and information technology awarded "Web Ratna" during the year 2012. The KSAMB in co-ordination with National Informatics Centre (NIC), Bangalore introduced a 'free mobile SMS alerts on market price' on $8^{\text {th }}$ February 2011 (Figure 1). By providing market information, this service is helping the market participants for taking better marketing decision. In order to avail the service, the market participants need to subscribe their cell phone numbers to the 'krishimaratavahini' website on a customized basis for commodities /varieties/ markets depending on their requirement. The number of crops and varieties covered by the KSAMB for dissemination of market information were 264 and 728, respectively at the time of chalking out this study. While the registered crops and varieties by the market participants were 166 and 106 , respectively. The maximum character length of a single message is 450 , which includes dispatched date, unit of measurement, market, commodity and variety name, and minimum and maximum price.

The Government of Karnataka has not made separate investment for the introduction of free mobile SMS alerts and also in creation of awareness about the services. The KSAMB and Department of Agricultural Marketing in collaboration with NIC have taken special interest in creation and design of the service. Further, the KSAMB has been given targets to the employees of marketing department/ APMC for creating awareness and subscription of market stakeholders through the regular training programmes to farmers. Apart from this, State Agricultural Universities have taken voluntary interest in popularizing the free SMS on agricultural prices through annual Krishi mela's (Kisan Mela). Further, the electronic and print media are also creating awareness about the usefulness of the service.

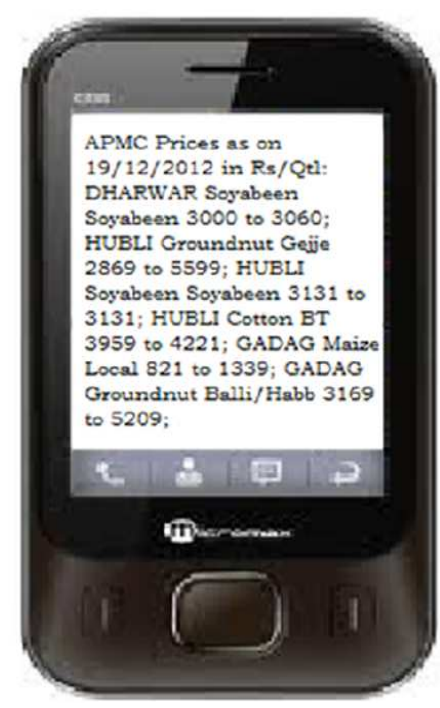

Fig 1. SMS Alerts on Agricultural Marketing prices

The article mainly focuses on the Impact of KSAMBs' free SMS alerts service to farmers on agricultural marketing prices in Karnataka. The remaining of the article include three sections: second section is focused on the data collection and methodological approach, third section on the results and discussion, and concluding remarks are offered at the end.

\section{Data Collection and Methodological Approach}

In order to fulfill the objective of the paper, both primary and secondary data were used. Secondary data were collected from NIC, Bangalore relating to the crop-wise farmers and sources of information dissemination for popularizing the service (farmers, APMC service, Govt. schemes, traders, news papers and radios,). Whereas the information relating to the type of technique or methodologies followed in disseminating price information to the farmers were collected from the KSAMB, Bangalore. The secondary information collected for study was from the date of start of the free SMS alerts (February, 2011 to February 2013).

Primary data were collected from the farmers through telephonic interview using pre- structured questionnaire. The farmers considered were those who have already registered mobile number for availing daily agricultural marketing prices at the Krishimaratavahini website. The registered mobile numbers of the farmers were collected from the NIC, Bangalore in the proportion of ten mobile numbers each across 11 crop categories: Cereals (maize and jowar), pulses (tur and bengal gram), oilseeds (groundnut and soybean), fruits (grape and banana), vegetables (onion and potato), spices (chilly and turmeric), flowers (rose and marigold), plantation crop (areca nut and copra ), fiber crops (cotton), dry fruits, forest products 
(soap nuts and tamarind). Thus, summing up, a total number of 110 farmers were surveyed telephonically through a structured questionnaire growing various crops. Both primary and secondary data was analyzed using descriptive analysis.

\section{Results and Discussions}

\subsection{Dissemination Process of SMS on Agricultural Marketing Prices}

Figure 2 presents the dissemination process of SMS (Short Message Service) on agricultural marketing prices. The employees/marketing supervisors of APMC's in the state are responsible for uploading the market information (prices and quantity arrival of notified commodities) to the 'Krishimaratavahini' website on all working days of the market. The dissemination of market prices starts at $16 \mathrm{hrs}$ onwards to the registered mobile phone subscribers on 'krishimaratavahini' website. This price information is being disseminated on daily basis by sending one text message per mobile phone and the information disseminating to each individual users exclusively depends on the preference indicated by the users based on their required market, commodities and varieties. In case of market holiday, the previous working day information is dispatched on that day by mentioning the previous date. The market participants include farmers, traders, APMC, Government schemes and media (Radio, TV, News Paper, etc).

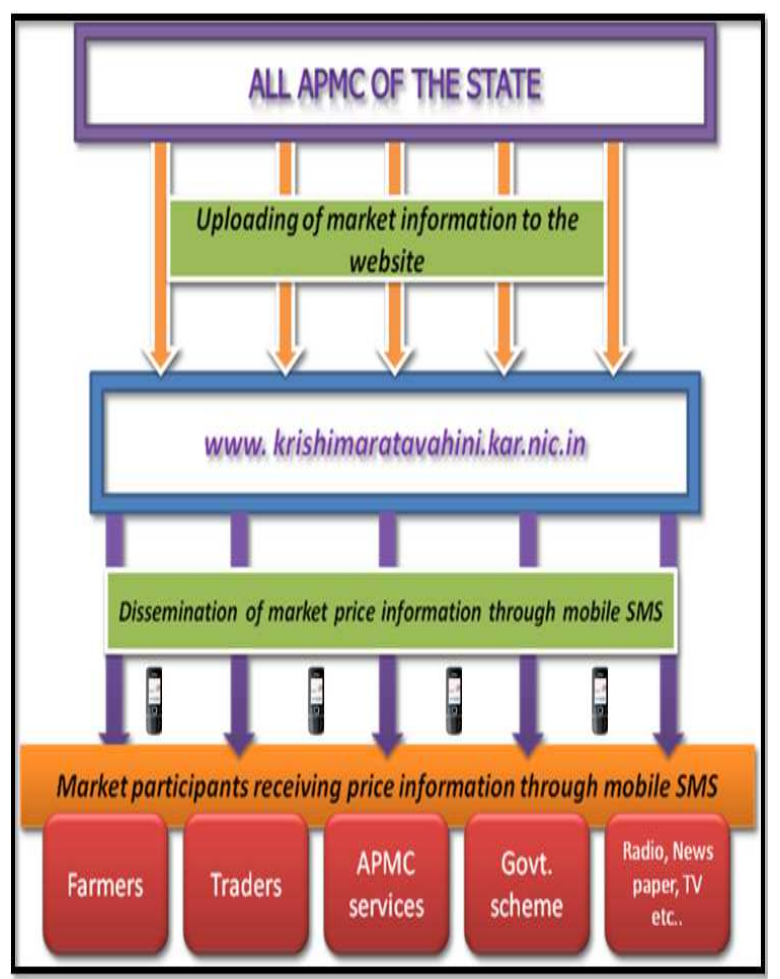

Figure 2. Dissemination process of SMS on agricultural marketing prices

\subsection{Categorization of Registered Users for Availing Free SMS on Market Prices}

The total number of registered market participants under different categories was 1, 20,071 individuals (table 1), which includes farmers, traders, commission agents, News paper and TV, radio. The farmer (89.26 per cent) comprises the highest portion of registered participants, followed by traders (4.14 per cent), APMC service (1.10 per cent), Government scheme ( 0.89 per cent $)$ and commission agents ( 0.63 per cent). Farmers, traders and commission agents were the targeted user for dissemination of market information and therefore their portion of coverage was found to be high i.e. 94.03 per cent. However, other registered participants like news paper, TV, radio and APMCs were found to be only 5.97 per cent, also targeting for dissemination of the same information through their respective ways.

\subsection{Impact of Free SMS on Agricultural Market Prices}

\subsubsection{Socioeconomic Profile of Sample Farmers}

The socioeconomic profile of sample farmers is presented in Table 2. The usage of mobile phone was found to be higher in the age group of 25 to 40 years $(46.36$ per cent), followed by age group of 41 to 60 years (40.00 per cent) (see Fig 3). This is due to obvious fact that the same age groups of farmers are actively involved in agricultural operations as well as adoption of improved technologies. Farmers with age group of more than 61 years were found to be less users of mobile SMS due to difficulty in application/understanding of mobile operations. The usage and felicity of operation of the gadgets has inversely proportional to the age groups of the respondents.

Table 1. Categorization of registered users for availing free SMS on market prices

\begin{tabular}{|c|c|c|}
\hline Categories & Number & per cent to the total \\
\hline Farmers & 107269 & 89.26 \\
\hline APMCs & 1322 & 1.10 \\
\hline Government scheme & 1072 & 0.89 \\
\hline Semi Government & 279 & 0.23 \\
\hline Traders & 4977 & 4.14 \\
\hline $\begin{array}{l}\text { Commission Agent } \\
\text { (CA) }\end{array}$ & 754 & 0.63 \\
\hline News paper/ TV/radio & 143 & 0.12 \\
\hline \multirow[t]{2}{*}{ Others } & 4355 & 3.62 \\
\hline & 120171 & 100.00 \\
\hline
\end{tabular}

Source: NIC, Bangalore, 2012 
Table 2. Socioeconomic profile of sample farmers

\begin{tabular}{|c|c|c|}
\hline $\begin{array}{l}\text { Socio-economic } \\
\text { features }\end{array}$ & $\begin{array}{l}\text { Number } \\
\text { beneficiaries }\end{array}$ & $\begin{array}{l}\text { per cent of farmers to } \\
\text { the total }\end{array}$ \\
\hline \multicolumn{3}{|l|}{ Age } \\
\hline $20-25$ & 10 & 9.09 \\
\hline $25-40$ & 51 & 46.36 \\
\hline $41-60$ & 44 & 40.00 \\
\hline$>61$ & 5 & 4.55 \\
\hline \multicolumn{3}{|l|}{$\begin{array}{l}\text { Education/Schooling } \\
\text { years }\end{array}$} \\
\hline Illiterate/Nil & 5 & 4.55 \\
\hline Primary school & 25 & 22.73 \\
\hline Secondary school & 20 & 18.18 \\
\hline PUC/12th std & 28 & 25.45 \\
\hline Degree programme & 32 & 29.09 \\
\hline \multicolumn{3}{|l|}{ Land holding } \\
\hline $\begin{array}{l}\text { Marginal farmer } \quad(< \\
2.5 \text { acre })\end{array}$ & 24 & 21.82 \\
\hline $\begin{array}{l}\text { Small farmers }(2.5-5 \\
\text { acre) }\end{array}$ & 29 & 26.36 \\
\hline $\begin{array}{l}\text { Medium farmers }(5- \\
10 \text { acre) }\end{array}$ & 35 & 31.82 \\
\hline $\begin{array}{l}\text { Large farmers }(>10 \\
\text { acre) }\end{array}$ & 22 & 20.00 \\
\hline
\end{tabular}

Further educational status of the farmers is considered as one of the important determinants for adoption of improved farming practices (Fig 4). Around 29 per cent of the registered sample farmers have done bachelors and masters degree, followed by primary (22 per cent), secondary (18 per cent) and higher secondary education ( 25 per cent). It was found that for obtaining agricultural market prices, farmers with higher education have selected English language, and farmers with low education have chosen local language (Kannada). But, remaining 4.5 per cent of the farmers were illiterate and they were not able to understand message and even they did not know how to open message box in the cell phone. Hence for this reason, these illiterate farmers had requested for voice SMS for easy and better understanding of information.

The land holding size is one of the determinants of financial status of farmers. The results demonstrate that around 52 per cent (Fig 5) of the beneficiaries belonged to medium and large farmers and remaining 48 per cent of the farmers were small and marginal farmers. Medium and large farmers had better advantage of the SMS information than small and marginal farmers in marketing of the produce due to the advantage of economies of scale (transportation, handling, selling in distant markets, etc.) and available marketable surplus. However, since, the technology is available in free of cost all the category of farmers were covered and which was usually missing in other service provider like RML, since they are charging some prices for getting information as found by study (Chahal et al 2012) showed that, RML scheme was being utilized for economic better off farmers like large and medium farmers. In another study (Menon et al, 2012), reported that, majority of the famers were small and marginal than of other categories of the farmers, this was again due to availability of information for free of cost and which was affordable to the farmers.

\subsubsection{Type of Markets Preferred By the Sample Farmers}

The highest percentages of sample farmers sold their produce at APMC market (83.72) due to easy access.

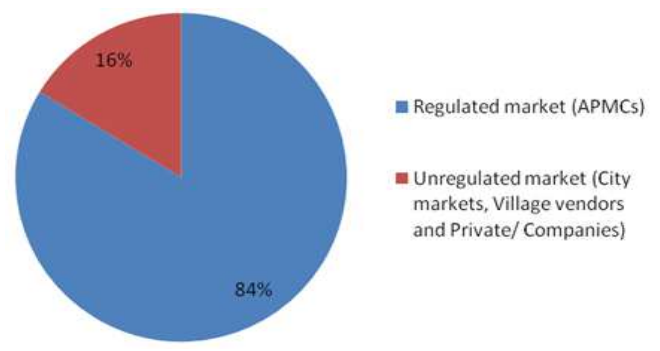

Fig 6. Types of markets preferred by the sample farmers (Percentage)

Only a few farmers who had grown perishable commodities (especially, vegetable, fruits and flowers), sold to unregulated markets like city markets, village vendors and private companies (16.28 per cent).

The reason for selling to unregulated markets (private companies, village vendors, city market) was relatively better price realization and other services like purchase from the field or village itself and quick payment. Particularly small and marginal farmers preferred village vendors for selling their produce due to lower quantity of production (Table 3 and Fig 6.).

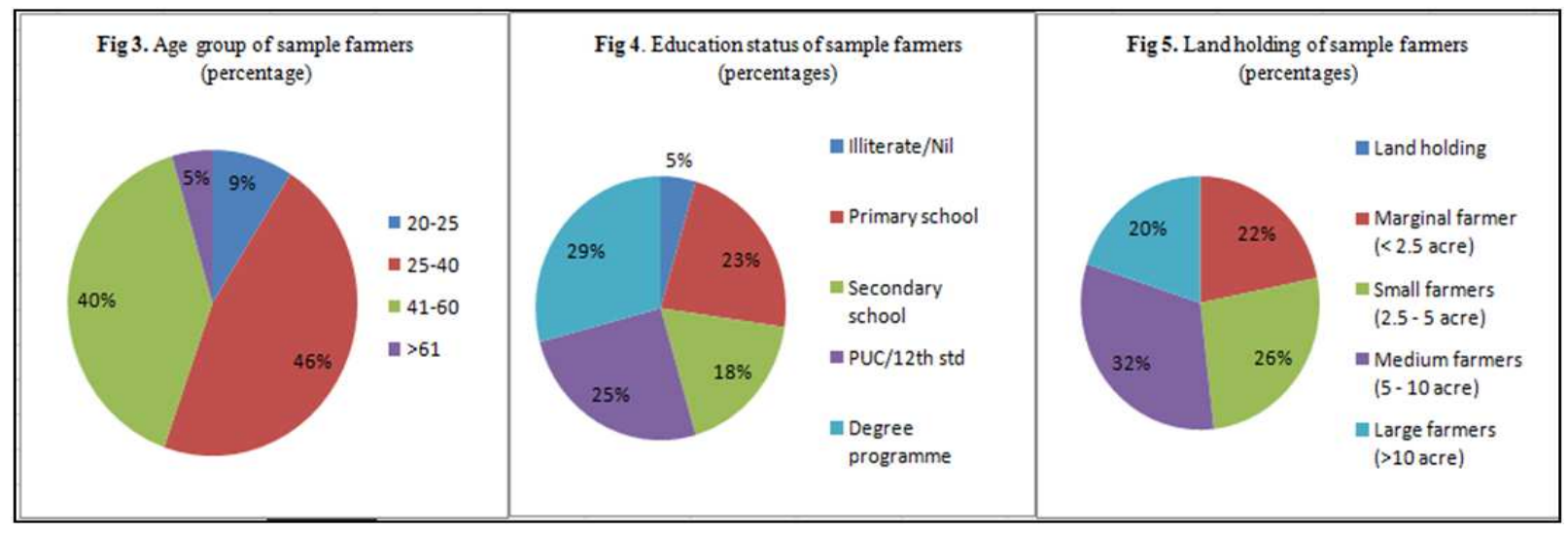

Figure 3, Figure 4 and Figure 5 describes Age group, Education Status and Land holding of Sample farmer 
Table 3. Types of markets preferred by the sample farmers

\begin{tabular}{lc}
\hline Market & per cent to the total \\
\hline Regulated market (APMCs) & 83.72 \\
Unregulated market (City markets, Village vendors and Private/ & 16.28 \\
Companies) & 100 \\
Total & 100 \\
\hline
\end{tabular}

\subsubsection{Adoption of Free SMS Subscription by the Sample Farmers}

Around 60 per cent of the beneficiaries had subscribed for the service for more than a year indicating that they were innovators or early adopters (Table 4 and Fig 7). Rest of the 40 per cent beneficiaries subscribed for the service for less than a year and hence can be considered as late adopters. On the performance side, the beneficiaries expressed their happiness towards timely availability of specific price information via SMS on their mobile phones. They also opined that such information was helping them taking an informed decision which ultimately was adding to their profitability.

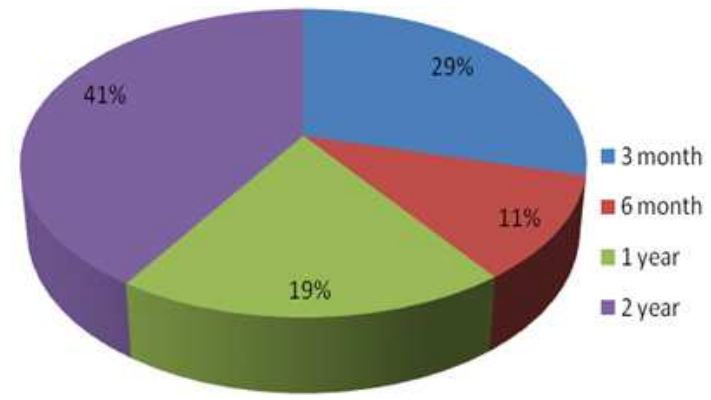

Fig 7. Duration of SMS service completed since from its subscription by the sample beneficiary (Percentage

\subsubsection{Economic Behavior and Constraints of Farmers through Utilization of Free SMS Services on Market Price}

It is interesting to note that sharing of free SMS alerts with peers by the selected beneficiaries were found to be 88.18 per cent. Around 12.73 per cent of the farmers opined that they were not receiving messages regularly on daily basis due to the lack of mobile network signals in the village. The other reason might be non-availability of particular commodities (due to off-season) in the market on that particular day (Table 5). Along with free SMS service on market prices, the marketing board has introduced another attractive service to the farmers i.e. Toll free number (1800-425-1552). The farmers can make a telephonic call and get the market price information of all the commodities in all the APMC's markets in Karnataka state at free of cost. However the awareness of service reveals that only 6.36 per cent of the beneficiaries were having knowledge about this information, mostly government servants and traders. There is a need of promotion of awareness initiatives about toll free service for enhancing the spread of market price information to farmers.

Table 4. Adoption of free SMS subscription by the sample farmers

\begin{tabular}{lcc}
\hline $\begin{array}{l}\text { Period of SMS service } \\
\text { since started }\end{array}$ & $\begin{array}{c}\text { No. of } \\
\text { beneficiaries }\end{array}$ & per cent \\
\hline 3 month & 32 & 29.09 \\
6 month & 12 & 10.91 \\
1 year & 21 & 19.09 \\
2 year & 45 & 40.91 \\
Total & 110 & 100.00 \\
\hline
\end{tabular}

Table 5. Economic behavior and constraints of farmers through utilization of free SMS services on market price

\begin{tabular}{llcc}
\hline Particulars & & Number & percent \\
\hline Sharing of SMS & Yes & 97 & 88.18 \\
& No & 13 & 11.82 \\
Difficulty in & Yes & 14 & 12.73 \\
receiving SMS & No & 96 & 87.27 \\
Awareness about & Yes & 7 & 6.36 \\
toll free No. 1800- & No & 103 & 93.64 \\
425-1552 & & & \\
\hline
\end{tabular}

4.3.5. Effectiveness of SMS Services in Terms of Timeliness, Accuracy, Content and Price Realization of the Disseminated Information

The effectiveness of SMS alerts on agricultural market price has been assessed by parameters such as timeliness of SMS reach, understanding of the SMS content, correctness of the SMS, and whether farmers benefit from such information. Most of beneficiaries ( 86.36 per cent) opined that they had been receiving daily SMS on the market prices (from $4 \mathrm{pm}$ to till $10 \mathrm{pm}$ ) for the registered commodities, which guided them in taking relatively better marketing decisions. However, vegetable growers demanded for SMS alerts twice a day instead of once a day because vegetable auctions operate twice a day i.e., once in the morning and the other in the evening (Table 6). About 79 per cent of the beneficiaries expressed that information was helpful and accurate, which assisted them selling their produce at right place and time. On the other hand, around 20 per cent of the beneficiaries (especially vegetable, fruits and flower growers) replied that the disseminated information was not accurate and more variation of prices was observed between disseminated and actual market prices. This might be due to higher fluctuations in prices of fruits, vegetables and flowers. As a result, farmers preferred to sell in the city market or through some private vendors like reliance fresh and other food retailing companies. In order to overcome inaccuracy in market price information the APMC employees should take care of 
promptness in uploading of accurate/ right information to the 'krishimaratavahini website' (Table 6).

Table 6. Effectiveness of SMS services in terms of timeliness, accuracy, content and price realization of the disseminated information

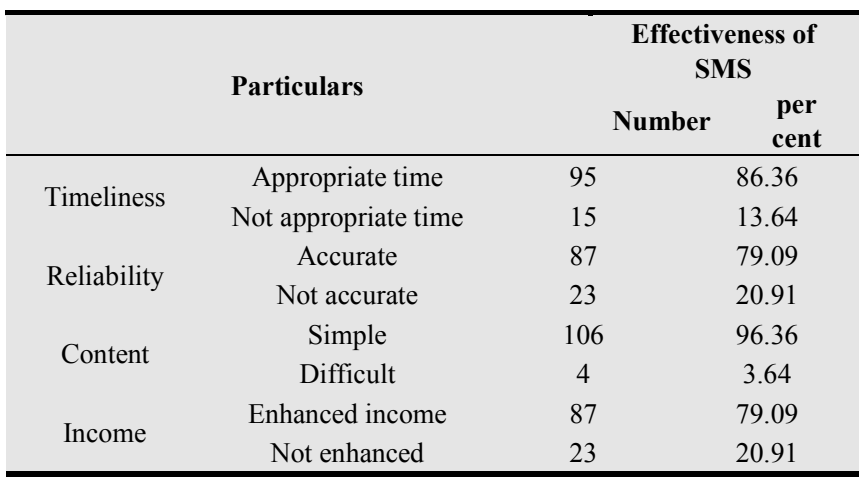

Content of information was found to be highly satisfactory to the beneficiaries (96.36 per cent). For instance the content of message in the SMS will appear like -APMC prices as on 10/02/2013 in Rs/Qtl: Hubli* ${ }^{*}$ soybean 2239 to 3111 . The message tells us the minimum and maximum prices of specified commodities at specified markets. Illiterate $(3.64 \%)$ farmers found difficulties in understanding the content of the SMS. They requested for the same information in voice SMS. With respect to price realization, around 80 per cent of the beneficiaries informed that the information was of great help for informed decision making (Table 6).

\subsubsection{Farmer's Suggestions towards Extending Other Agricultural Information Coverage through Free Mobile SMS Services}

The details presented in Table 7 points out that the farmers desired for extending the existing SMS service by supplementing additional information such as weather and price forecasts, usage of plant protection chemicals, etc. The information needs to be in the text and voice formats. The highest percentage of farmers had suggested for voice SMS (85.45 per cent). Beneficiaries asked for other services like weather (75.45 per cent), price forecasts (55.45 per cent), pesticide (40 per cent) and weedicide information (39per cent). The farmers expressed the view that price forecast information at the time of harvesting would help them making better decisions.

Table 7. Farmer's suggestions for extending of free SMS services for availing other agricultural information

\begin{tabular}{ccc}
\hline Desired information & Number & per cent \\
\hline Weather forecast & 83 & 75.45 \\
Forecast price & 61 & 55.45 \\
Plant protection Pesticide & 44 & 40.00 \\
Weed management & 43 & 39.09 \\
Voice SMS service & 94 & 85.45 \\
\hline
\end{tabular}

\section{Conclusions and Policy Suggestions}

The results demonstrate that the dissemination of market prices through mobile SMS alerts was found to be very important service to the market participants in improving their profits by their informed decision making. Further, it helped the market participants in reducing their marketing costs and time by avoiding frequent visits to the market for getting price information. It also garnered confidence to the farming community by providing them information from authentic sources. The market participants (farmers, traders, commission agents, etc.) of durable or semi perishable commodities realized higher profits by making better decisions of selling their produce at right place and time. In comparison, farmers who were handling perishable commodities like fruits, vegetables and flower crops realized lesser benefits from the SMS service because of relatively inaccurate price information due to wide fluctuations, less market coverage of these products, and less arrivals to the regulated markets. The study reveals that SMS is very helpful to the farming community in the state, but extent of its publicity need to be enhanced. Most of the surveyed farmers requested for extending the existing SMS by supplementing additional information such as weather and price forecasts, usage of plant protection chemicals etc., as well as, providing the same as voice messaging, the scheme can be further improved by reducing the above mentioned drawbacks and further extending the service to more and more farmers and other stakeholders. The lessons learnt from the Karnataka's experience can provide useful information for implementation of the same service in improved formats in other states and also introduction of similar type of services at the AGMARKNET (Agricultural Marketing Information Network, which is act wise nationwide information network for speedy collection and dissemination of market information in the country) and further, Govt. should take a special interest in establishing a separate agency for dissemination of all the agricultural information in the local language to all the states stakeholders at free of cost in order to reach large proportion of beneficiaries throughout India.

\section{Acknowledgements}

This study was undertaken by the author (Ganeshagouda I. Patil) under ICAR, three month professional attachment training at Institute for Social and Economic Change (ISEC), Bangalore. Author ${ }^{1}$ expressed whole hearted thanks and deep sense of gratitude to Dr. Ramesh Chand, Director, National Centre for Agricultural Economics and Policy Research, New Delhi, for providing me an opportunity of training at ISEC, Bangalore. Author, also extended heart full thanks to the esteemed mentor, Dr. Parmod Kumar, professor at ISEC for his expert guidance, keen interest, untiring attention and invaluable support evinced throughout the course of my training. Finally, I express my sincere thanks Science publishing group for 
accepting our paper for publication in their esteemed journal.

\section{References}

[1] Meera, S., Jhamtani, A. and RAo, D. U. M. (2004) information and communication technology in agriculture development: A comprehensive development of three projects from India, Agriculture Research and Extension Network, paper No.135.

[2] Bahl, M. (2008) S\&T for rural india and inclusive growth: ICT in agricultural marketing culled from www.nstads.res.in

[3] USAID (2010) ICT to enhance farm extension service in Africa, Briefing paper, November
[4] Chahal S.S., Sidhu M.S. and Parminder Kaur (2012) 'Impact assessment of Reuters Market Light (RML) in agricultural information dissemination in Punjab' Agricultural Economics Research Review, 25: 373-378.

[5] Menon S. J., Raju V. K. and Simmy V.V. (2012), 'Effectiveness of mobile phone based agricultural information alerts', International Journal of Current Research, 4(2): 72-75

[6] Civil services chronicle April, 2012, xxii No. 10: 145

[7] www.krishimaratavahini.nic.in

[8] www.agmarknet.nic.in 